\title{
Toronto 2006
}

\author{
By Brandon Wee
}

Fall 2006 Issue of KINEMA

\section{HIGHLIGHTS FROM THE TORONTO INTERNATIONAL FILM FESTIVAL 2006}

North America's largest film festival came and went with some 350 films for its $31^{\text {st }}$ edition. Toronto's prominence has as much to do with it being Hollywood's choice of setting for its fall product launches as it does with its time-sensitive obligation to introduce the currency of world cinema to domestic theatrical markets. This year however, films endowed with prestigious budgets or prizes failed to garner general favour. Here are notes on ten titles deemed too unfamiliar by a mainstream media fixated on familiarity:

2:37 (Murali K. Thalluri, Australia 2006)

In a stunning debut, a director just past his teenage years injects the high school coming-of-age genre with a subversive dose of adrenaline. Opening with the discovery of a suicide in a school but without revealing the deceased, 2:37 peels away in flashback and introduces several characters all in various extremities of growing pains. Who then will die at their own hands? Conceived as a radically different whodunit, Thalluri's chronological and narrative rhythms are exceptional, and although dotted by some aching overplay, this amateur ensemble is otherwise first-rate.

Belle toujours (Manoel de Oliveira, Portugal-France 2006)

More an inspired experiment than a "sequel," Belle toujours follows where Luis Buñuel's Belle de jour left off 39 years ago. Michel Piccoli reprises the rapacious Henri Husson, but Bulle Ogier replaces Catherine Deneuve's Séverine. After reuniting by chance in Paris, Husson learns that Séverine has abandoned her deviant past for a life of seclusion. But for her, the question of whether he had divulged her secret still haunts her bitterly. Too respectful of Buñuel to provide 'the' answer, De Oliveira gleefully teases this issue instead, and allows the resulting joke to fall squarely on one obvious party.

The Bet Collector (Jeffrey Jeturian, The Philippines 2006)

The popular but illegal Philippine pastime of jueteng (a lottery where two sets of numbers are wagered) underpins the story of a bet collector who earns her keep by nibbling on the meager commissions of her syndicate. Thinly disguised as social commentary (the opening titles preface that jueteng kickbacks have allegedly enriched the former and current presidents), Jeturian's eye trains on the pawns inhabiting the lower echelons of the game. Gina Pareño's performance as the kubrador provides a captivating study of the dilemmas that this social habit generates.

Bliss (Sheng Zhimin, China 2006)

A rewarding experience awaits the patient viewer of this quiet observation of a Chongqing family fractured by circumstance - when the ashes of a retiree's estranged first wife are sent to him long after he has remarried. Although the effect is muted, the upheaval on both his families is no less distressing. Disguised as a brooding essay on mortality and existential anxieties, episodic scrutiny of individual characters culminates in a fuller, more satisfying portrait. Chongqing, doused in perpetual mist, offers a compelling metaphor for the miasmalike quality of tensions that are always simmering but never quite erupt.

Exiled (Johnnie To, HK-China 2006)

Johnnie To can charm after all. After tedious attempts at cops-and-robbers escapades in PTU and Breaking News, To scores solid footing in the triad underworld with his hat trick of Election, Election 2, and now, Exiled. Easily a spin-off from The Mission, it centres on two pairs of chummy hit men who clash between killing an associate on orders and saving him on affinity. Endlessly stylised, coupled with a compelling mix of drollness and melancholy, Exiled returns home a winner. Richie Ren's hilarious cameo completes a gifted ensemble fronted by Francis Ng, Anthony Wong, and Simon Yam.

Half Moon (Bahman Ghobadi, Iran-Iraq-Austria-France 2006)

To fulfill a long-standing aspiration, a retired Kurdish musician is determined to travel between the Iranian and Iraqi borders of Kurdistan to perform at a concert. Despite being granted official permission, the odds 
standing in his way include a clairvoyant's advice against the journey and a desire to smuggle a woman across the border - an exiled singer whose celestial voice the musician believes is crucial to the performance. Poignant and sublime, Ghobadi uses lyrical allegory to question the relevance of national borders and its grievous effect on Kurdish culture. Predictably, Half Moon has been banned in Iran.

Jindabyne (Ray Lawrence, Australia 2006)

A hard question in ethics moors Ray Lawrence's introspective study of this eponymous town up in arms after a group of men discover the body of a young girl during a fishing trip but decide not to immediately report the news. What they deem as inculpable in defence is quickly countered by a huge communal backlash: the police and their wives are incensed at their lack of mortification, while the victim's kin and supporters allege racism. Laura Linney excels as the town's only individual committed to righting her husband's (Gabriel Byrne) wrong.

Opera Jawa (Garin Nugroho, Indonesia-Austria 2006)

A very different spin on the musical genre, Opera Jawa unites the expertise of practitioners of Javanese dance, music and theatre alongside contemporary installation and performance artists as they perform Nugroho's adaptation of "The Abduction of Sinta" from the Ramayana, which recounts the epic tragedy of a love triangle. Each set of choreographed performances is entrancing, as is the sonorous gamelan orchestra that underscores the intricate blend of song and movement. Billed as "A Cinema Requiem," Opera Jawa uses Indonesia's multicultural specificity as a plea for universal pacifism.

Syndromes and a Century (Apichatpong Weerasethakul, Thailand-France-Austria 2006)

"Incomprehensibility" is a term denoting either passive abuse or active affection levelled at Apichatpong's films. His latest is without exception. Its Thai title translating as "Light of the Century," the film is an examination of architectural space as it relates to personal memory, with the central characters inspired by Apichatpong's parents, who as doctors, raised him in hospitals. Two segments unfold congruently, where each is set in a hospital. Although both share similar characters and proceedings, they ultimately differ metaphysically. The film's antiseptic feel is perhaps not coincidental, wherein a chilling ambiance figures prominently.

When The Levees Broke: A Requiem in Four Acts (Spike Lee, USA 2006)

Spike Lee's dirge in tribute of what was reportedly a natural disaster doubles as his redoubtable indictment of George Bush's administration for mishandling Hurricane Katrina. Challenging mainstream narratives, Lee's interviewees, both directly and indirectly affected, allege that the cataclysm could have been avoided had New Orleans' infrastructure benefited from solid government supervision. Unfortunately, this festering neglect would set the stage for a domino effect following the deadly deluge, with accusations against the government for being oppressive, racist, and worst, indifferent to the swelling plight - charges Lee credibly puts forth cases for.

\section{Author Information}

Brandon WEE lives in Toronto. He has written for Asia Pacific Arts (Los Angeles), Cineaste (New York), Cinema Scope (Toronto), Ricepaper (Vancouver), and Senses of Cinema (Melbourne). 